\title{
Contribution of Smoking to Pulmonary Tuberculosis Incidence in Bandung, Indonesia
}

\author{
Raspati Cundarani Koesoemadinataa,,2,3, Panji Fortuna Hadisoemarto',4, \\ Manik Intan Gumilang5, Ida Parwati Santoso ${ }^{1,6}$, Bachti Alisjahbana ${ }^{1,7}$ \\ ${ }^{1}$ Research Center for Care and Control of Infectious Disease, Universitas Padjadjaran, \\ Bandung, Indonesia. \\ ${ }^{2}$ Department of Internal Medicine, Radboud Institute for Health Sciences, \\ Radboud University Medical Center, Nijmegen, The Netherlands. \\ 3Indonesian Society for Clinical Microbiology, Bandung, Indonesia. \\ 4Department of Public Health, Faculty of Medicine, Universitas Padjadjaran, Bandung, Indonesia \\ 5Undergraduate Programme, Faculty of Medicine, Universitas Padjadjaran, Bandung, Indonesia. \\ ${ }^{6}$ Department of Clinical Pathology, Faculty of Medicine, Universitas Padjadjaran/ \\ Dr Hasan Sadikin General Hospital, Bandung, Indonesia. \\ 7Department of Internal Medicine, Faculty of Medicine, Universitas Padjadjaran/ \\ Dr Hasan Sadikin General Hospital, Bandung, Indonesia
}

\section{ABSTRACT}

Background: Primary data reporting the contribution of smoking to tuberculosis (TB) incidence in Indonesia are scarce. This study aimed to estimate the effect of smoking on TB incidence and the risk of tuberculosis attributable to smoking among presumptive TB patients in Indonesia, a country with the third highest incidence of TB globally which one third of its population are active smokers.

Subjects and Method: Between 2012-2014, presumptive TB patients aged $\geq 15$ years old presenting with cough for at least 2 weeks to Dr. Hasan Sadikin General Hospital Bandung, Indonesia underwent interview, chest x-ray examination, and were asked to provide 2 sputa for microscopic examination and Mycobacterium tuberculosisculture. The prevalence of smoking and bacteriologically confirmed TB among these patients and their corresponding confidence interval (CI) was determined. Dependent variable was TB. The independent variables were smoking, age, and gender. A multiple logistic regression was used to assess the association between smoking category with bacteriologically confirmed TB controlling for age and gender.

Cite this as:

Koesoemadinata RC, Hadisoemarto PF, Gumilang MI, Santoso IP, Alisjahbana B (2020). Contribution of Smoking to Pulmonary Tuberculosis Incidence in Bandung, Indonesia. J Epidemiol Public Health. 05(04): 451-457. https://doi.org/10.26911/jepublichealth.2020.05.04.07.

(c) (i) (2) Journal of Epidemiology and Public Healthis licensed under a Creative Commons

Journal of Epidemiology and Public Healthis licensed under a Crea
Results: Of 198 presumptive TB patients (58.1\% males, median age 40 years old), 101 (51.0\%; 95\% CI= 43.8 to 58.2 ) were eversmoker and $71(35.9 \%$; $95 \% \mathrm{CI}=29.2$ to 43.0$)$ had bacteriologically confirmed TB. Eversmoking was associated with an increase bacteriologically confirmed $\mathrm{TB}$ incidence $(\mathrm{aOR}=$ 2.95; $95 \% \mathrm{CI}=1.36$ to $6.40 ; \mathrm{p}=0.006)$. The incidence of bacteriologically confirmed TB that was attributable to smoking (population attributable proportion) was $22.3 \%(95 \% \mathrm{CI}=16.6$ to 28.7).

Conclusion: Smoking increases risk of acquiring TB. Smoking cessation program should be promoted as an intervention to reduce $\mathrm{TB}$ incidence and prevent $\mathrm{TB}$ transmission.

Keywords: Smoking, TB, attributable proportion

\section{Correspondence:}

Raspati Koesoemadinata. Research Center for Care and Control of Infectious Disease, Universitas Padjadjaran, Bandung, Indonesia. Mobile: 082218307880. Email: r.c.koesoemadinata@unpad.ac.id. 


\section{BACKGROUND}

With more than 500 thousand tuberculosis (TB) cases reported in 2019, Indonesia was one of five countries that account for more than half of the global total TB cases (WHO, 2020). One third of Indonesians, including two-thirds of Indonesian males, aged 15 years or older were smokers (Lange, 2018). Even though smoking is one of the wellknown risk factor for acquiring TB (Bates, 2007; Lin, 2007), primary data reporting the contribution of smoking to TB incidence in Indonesia are scarce. The End TB strategy (Uplekar, 2015) and the Indonesian TB program (Kementerian Kesehatan RI, 2018) have recognized smoking as a risk factor for TB. However, currently there is no operationalization on smoking cessation program in the TB control program. This study aimed to estimate the effect of smoking on TB incidence and the risk of tuberculosis attributable to smoking among presumptive TB patients in Bandung, Indonesia.

\section{SUBJECTS AND METHOD}

\section{Study Design}

A secondary analysis was done on data collected through a cross-sectional study conducted between 2012-2014, in Dr. Hasan Sadikin General Hospital, Bandung. The primary study was a cross-sectional study aimed to evaluate a diagnostic test for TB disease.

\section{Population and Sample}

Presumptive TB patients aged $\geq 15$ years presenting to the Clinical Pathology Laboratory at Hasan Sadikin General Hospital with a cough of at least 2 weeks duration and a clinical decision to investigate for pulmonary TB. Those who smoked cigarette within 2 hours of the investigation, refused informed consent, and previously diagnosed and treated for TB were excluded from this study.

\section{Study Variables}

Dependent variable of the study was bacteriologically confirmed TB case. Independent variables included in the study were gender, age, smoking status, and smoking exposure.

\section{Operational Definition of Variables} Bacteriologically confirmed TB case was defined as TB case based on positive acid-fast bacilli (AFB) and/or Mycobacterium tuberculosis (Mtb) culture.

Gender is a binomial variable, male or female.

Age is a numerical variable, defined as the length of time that a person has lived, measured in years. Age was classified into two categories using median age as cutoff.

Smoking status was categorized into two groups, i.e., ever-smoker (current and exsmokers) and never-smoker.

Smoking exposure variable consisted of three groups: (1) unexposed; these were subjects who had never smoked and did not live with smokers, (2) second-hand smoker; defined as subjects who did not smoke but lived in the same household with smokers, and (3) first-hand smokers; subjects who were current or ex-smokers.

\section{Study Instruments}

Study participants underwent interview, chest X-ray (CXR), and were asked to provide 3 sputa (spot-morning-spot). Socio-demographic and smoking exposure data were collected using an intervieweradministrated questionnaire. Sputum microscopic AFB examination was done using Ziehl Neelsen staining and $M t b$ culture was performed using Lowenstein Jensen (LJ) media. CXR result were read by an infectious disease specialist.

\section{Data Analysis}

The main study recruited 200 presumptive TB patients. We estimated that $60 \%$ of the participants would be ever-smoker and $30 \%$ would have bacteriologically confirm- 
ed TB. Using Fisher's exact test, it can be estimated that the power is $97.5 \%$ to detect an odds ratio of 2:1. The prevalence of smoking and bacteriologically confirmed TB participants among presumptive TB patients and its corresponding 95\% confidence interval (CI) was determined. The characteristics of study population were compared according to smoking status using Chi Squared test. The association between smoking status and smoking exposure with bacteriologically confirmed TB was assessed using bivariate analysis and presented as crude odds ratio (OR); and using multivariate logistic regression controlling for age and gender and presented as adjusted odds ratio (AOR). Attributable risk (AR) was calculated by subtracting the risk of $\mathrm{TB}$ cases in eversmoking group with the risk of TB cases in never-smoking group. Population attributable proportion (PAP) was estimated by subtracting the risk of TB cases in total presumptive TB recruited with the risk of TB cases in never-smoking group. Statistical analyses were carried out using Stata 13.0 (StataCorp, College Station, TX, USA).

\section{Research Ethics}

The main study was approved by Health Research Ethics Committee, Faculty of Medicine, Universitas Padjadjaran No. LB.04.01/A05/EC/112/XII/2012 and written informed consent was obtained from all patients prior to inclusion. The secondary data analysis was approved by the Health Research Ethics Committee, Faculty of Medicine, Universitas Padjadjaran No. 1218/UN6.KEP/EC/2019.

\section{RESULTS}

1. Sample Characteristics

Of 200 presumptive TB patients recruited, 198 (99\%) had a complete AFB result and were included in the analysis. Median age was 40 (range 15-89) years old.

\section{Table 1. Characteristics of study participants}

\begin{tabular}{llcc}
\hline \multicolumn{1}{c}{ Characteristics } & \multicolumn{1}{c}{ Category } & Frequency & Percentage \\
\hline Gender & Male & 115 & 58.1 \\
Age (years) & Female & 83 & 41.9 \\
Smoking status & $>40$ & 98 & 49.5 \\
& $\leq 40$ & 100 & 50.5 \\
Smoking exposure & Ever & 101 & 51.0 \\
& Never & 97 & 49.0 \\
& No exposure & 34 & 17.2 \\
Chest X-ray & Passive smoker & 63 & 31.8 \\
& Active smoker & 101 & 51.0 \\
Acid Fast Bacilli & Suggestive TB & 94 & 54.7 \\
& Abnormal not TB & 41 & 23.8 \\
& Normal & 37 & 21.5 \\
& Positive 3 & 12 & 5.1 \\
& Positive 2 & 11 & 5.6 \\
Mtb culture & Positive 1 & 25 & 12.6 \\
& Scanty & 3 & 1.5 \\
& Negative & 147 & 74.2 \\
& Positive & 55 & 27.8 \\
& Negative & 118 & 59.6 \\
\hline
\end{tabular}

Of 198 patients included, 115 (58.1\%) patients were males, 101 (51.0\%; 95\% CI
43.8-58.2) were ever-smoker, 63 (31.8\%) were second-hand smoker, 94 (47.5\%) had 
a chest $\mathrm{x}$-ray suggestive of $\mathrm{TB}$, and 51 (25.8\%) patients had a positive AFB result (Table 1). Among 147 patients with negative $\mathrm{AFB}, 20$ patients had a positive culture result. Therefore, 71 patients were bacteriologically confirmed TB $(35.9 \%$; $95 \% \mathrm{CI}=$ 29.2 to 43.0 ).

\section{Bivariate and Multivariate Analysis}

Bacteriologically confirmed TB was strongly associated with smoking status (Table 2). Patients who ever-smoked was twice as likely to have TB compared to those who never-smoked (crude OR= 2.00; 95\% $\mathrm{CI}=$ 1.10 to $3.62 ; \mathrm{p}=0.021)$. The dose-response relationship between $\mathrm{TB}$ and smoking exposure is displayed in Table 2. Using unexposed group as the reference, patients who were a second-hand smoker had an increased odd of having bacteriologically confirmed $\mathrm{TB}(\mathrm{OR}=3.11 ; 95 \% \mathrm{CI}=1.02$ to 9.47; 0.035) and the odds for first-hand smokers was even higher $(\mathrm{OR}=4.48 ; 95 \%$ $\mathrm{CI}=1.54-13.03 ; \mathrm{p}=0.003)$.

Table 2. Patients' characteristics with bacteriologically confirmed TB

\begin{tabular}{|c|c|c|c|c|c|c|}
\hline \multirow{3}{*}{ Independent Variable } & \multicolumn{4}{|c|}{ Bacteriologically confirmed TB } & \multirow{3}{*}{ OR } & \multirow{3}{*}{$\mathbf{p}$} \\
\hline & \multicolumn{2}{|c|}{ No } & \multicolumn{2}{|c|}{ Yes } & & \\
\hline & $\mathbf{N}$ & $\%$ & $\mathbf{N}$ & $\%$ & & \\
\hline \multicolumn{7}{|l|}{ Gender } \\
\hline Male & 74 & 58.3 & 41 & 57.8 & \multirow{3}{*}{$\begin{array}{c}0.98 \\
\text { ref }\end{array}$} & \multirow[t]{3}{*}{0.943} \\
\hline Female & 53 & 41.7 & 30 & 42.2 & & \\
\hline \multicolumn{5}{|l|}{ Age } & & \\
\hline$>40$ & 70 & 55.1 & 28 & 39.4 & 1.88 & \multirow[t]{3}{*}{0.035} \\
\hline $\begin{array}{l}\leq 40 \\
\text { Smoling ctatus }\end{array}$ & 57 & 44.9 & 43 & 60.6 & \multirow[t]{2}{*}{ ref } & \\
\hline \multicolumn{5}{|l|}{ Smoking status } & & \\
\hline $\begin{array}{l}\text { Ever } \\
\text { Never }\end{array}$ & $\begin{array}{l}5 / \\
70\end{array}$ & $\begin{array}{l}44.9 \\
55.1\end{array}$ & $\begin{array}{l}44 \\
27\end{array}$ & $\begin{array}{l}62.0 \\
38.0\end{array}$ & \multirow{2}{*}{ ref } & \multirow{2}{*}{0.021} \\
\hline \multicolumn{5}{|l|}{ Smoking exposure } & & \\
\hline Active smoker & 57 & 44.9 & 44 & 62.0 & 4.48 & 0.003 \\
\hline Passive smoker & 41 & 32.3 & 22 & 31.0 & 3.11 & 0.035 \\
\hline No exposure & 29 & 22.8 & 5 & 7.0 & ref & \\
\hline
\end{tabular}

Abbreviation: $\mathrm{TB}=$ tuberculosis

Adjusted by age and gender, the association between ever-smoking with bacteriologically confirmed TB case remained

Table 3. The result of multiple logistic regression analysis

\begin{tabular}{lcccc}
\hline \multirow{2}{*}{ Independent variables } & \multirow{2}{*}{ aOR } & \multicolumn{2}{c}{$\mathbf{9 5 \%}$ Confidence Interval } & \multirow{2}{*}{ Lower limit } \\
\cline { 3 - 4 } Smoking & 2.95 & 1.36 & Upper limit & p \\
Age category & 1.89 & 1.03 & 3.40 & 0.006 \\
Gender & 0.52 & 0.24 & 1.13 & 0.039 \\
N observation $=198$ & & & & \\
-2 log likelihood $=-122.91$ & & & & \\
Nagelkerke $\mathrm{R}^{2}=4.88 \%$ & & & & \\
\hline
\end{tabular}

\section{Population Attributable Proportion}

The proportion of bacteriologically confirmed TB in ever-smoker that was attri- significant $(\mathrm{aOR}=2.95 ; 95 \% \mathrm{CI}=1.36$ to $6.40 ; \mathrm{p}=0.006)($ Table 3$)$. buted to smoking (AR) was $8.6 \%$ (95\% CI 5.1-13.4) and the incidence of bacteriologically confirmed $\mathrm{TB}$ in presumptive $\mathrm{TB}$ 
patients that was attributable to smoking (PAP) was $22.3 \%$ (95\% $\mathrm{CI}=16.6$ to 28.7 ).

\section{DISCUSSION}

Ever-smoking is associated with bacteriologically confirmed TB in our study. This is in line with systematic review and meta-analysis studies conducted in 2007 (Bates, 2007). The aOR in our study (2.95) is similar to the studies in high burden countries included in the reviews (3.20 in Pakistan, 2.31 in Vietnam, etc.). First-hand smokers have the highest odds of having bacteriologically confirmed TB in our study, suggesting a dose-response relationship which has also been found in a large study in China(Zhang, 2017).An increased risk among second-hand smokers in our study was not as high as the risk in first-hand smokers which was also stated in a review in 2015(Dogar, 2015). The PAP in our study (22.3\%; 95\% CI 16.6-28.7) confirms the estimate done by Amere et al (24.9\%; 95\% CI 13.2-29.1), suggesting that smoking is accounted for more than 1 of every 5 new TB cases(Amere, 2018).

The prevalence of ever-smoker in our study (51\%; 95\% CI 43.8-58.2) was higher than the general population in Indonesia (31.0\%). Stratified according to gender, 86/198 (43.4\%) males and 15/198 (7.6\%) females ever smoked in our study, compared to $59.9 \%$ males and $2.0 \%$ females in the general population. The prevalence of ever-smoker in our study wasalso higher compared to presumptive TB patients South India (41\%; 95\% CI 36.9 to 46.3 ) (Kanakia, 2016), but probably because we included all ever-smoker in our study while the other study defined tobacco users as those who ever smoked in the last 1 month prior to enrolment. Among those who were later diagnosed with $\mathrm{TB}$, the prevalence of ever-smoker in our study was only slightly higher (85.2\% vs $80.8 \%)$. Similarly, both studies found a strong association between male gender and smoking.

Our study has several limitations. We could not take into account other potential confounders on the association between smoking and TB because the primary study did not collect this information. A proportion of the patients did not have a culture result, which may lead to an underestimated proportion of bacteriologically confirmed TB. We did not perform detailed questions about the frequency of smoking and there may be misclassification in the smoking status and smoking exposure among the participants.

However, our study suggests that smoking is an important risk factor for pulmonary $\mathrm{TB}$ in Bandung, Indonesia. Given the fact that the outcome is bacteriologically confirmed TB, removing smoking from the society may likely to reduce active transmission of TB. Furthermore, smoking cessation program is critically important since smoking is also known to be associated with poor treatment outcomes (Leung, 2015). There is no smoking cessation operationalization in the national TB program, but a study in Yogyakarta (Nichter, 2016) introduced an intervention that may be applied in TB clinics.

We reported a high prevalence of ever-smoker among presumptive TB patients in an out-patient setting in Bandung, Indonesia. We found a strong association between ever-smoking and bacteriologically confirmed TB, a dose-response relationship between smoking exposure with TB, and a relatively high population attributable proportion to conclude that smoking is indeed an important risk factor for TB. We recommend including an intervention to reduce smoking in the community as part of the National TB program. 


\section{AUTHOR CONTRIBUTION}

Raspati Cundarani Koesoemadinata designed the study. Manik Intan Gumilang validate and verified data collected. Raspati Cundarani Koesoemadinata wrote the first manuscript draft. Panji Fortuna Hadisoemarto, Ida Parwati Santoso, and Bachti Alisjahbana reviewed and edit the manuscript. All authors read and approved the final draft.

\section{CONFLICT OF INTEREST}

None declared.

\section{FUNDING AND SPONSORSHIP}

The study was a secondary analysis and no funding required. The authors did not receive any funding.

\section{ACKNOWLEDGEMENT}

We thank Dr Lya Sevtyani and staff in the Department of Clinical Pathology, Dr. Hasan Sadikin General Hospital, Bandung, for giving permission to collect the data.

\section{REFERENCE}

Amere GA, Nayak P, Salindri AD, Narayan KMV, Magee MJ (2018). Contribution of smoking to tuberculosis incidence and mortality in high-tuberculosisburden countries. Am J Epidemiol. 187(9): 1846-1855.

Bates MN, Khalakdina A, Pai M, Chang L, Lessa F, Smith KR (2007). Risk of tuberculosis from exposure to tobacco smoke. Arch Intern Med. 167(4): 335342.

Dogar OF, Pillai N, Safdar N, Shah SK, Zahid R, Siddiqi K (2015). Secondhand smoke and the risk of tuberculosis: A systematic review and a meta-analysis. Epidemiol Infect. 143 (15): 3158-3172. doi: 10.1017/So950268815001235 .

Kanakia KP, Majella MG, Thekkur P,
Ramaswamy G, Nair D, Chinnakali P (2016). High tobacco use among presumptive tuberculosis patients, South India: Time to integrate control of two epidemics. Osong Public Health Res Perspect. 7(4): 228-232. doi: 10.1016/j.phrp.2016.06.001.

Kementrian Kesehatan RI (2018). Protokol Riset Kesehatan Dasar 2018. Kementerian Kesehatan Republik Indonesia.

LangeC, Chesov D, Heyckendorf J, Leung CC, Udwadia Z, Dheda K (2018). Drug-resistant tuberculosis: An update on disease burden, diagnosis and treatment. Respirology. 23(7): 656-673. doi: 10.1111/resp.13304.

Leung CC, Yew WW, Chan CK, Chang KC, Law WS, Lee SN, et al. (2015). Smoking adversely affects treatment response, outcome and relapse in tuberculosis. Eur Respir J. 45(3): 738-745. doi: 10.1183/09031936.00114214.

Lin HH, Ezzati M, Murray M (2007). Tobacco smoke, indoor air pollution and tuberculosis: A systematic review and meta-analysis. PLoS Med. 4(1): 0173-0189. doi: 10.1371/journal.pmed.0040020.

Nichter M, Padmawati S, Ng N (2016). Introducing smoking cessation to Indonesian males treated for tuberculosis: The challenges of lowmoderate level smoking. Soc Sci Med. 152: 70-79. doi: 10.1016/j.socscimed.2016.01.028.

Uplekar M, Weil D, Lonnroth K, Jaramillo E, Lienhardt C, Dias HM, et al. (2015). WHO's new end TB strategy. The Lancet. 385(9979): 1799-1801. doi: 10.1016/So140-6736(15)60570-0.

World Health Organization (2020). Global tuberculosis report 2020. WHO, Geneva.

ZhangH, Xin H, Li X, Li H, Li M, Lu W, et 
Koesoemadinata et al./ Contribution of Smoking to Pulmonary Tuberculosis

al. (2017). A dose-response relationship of smoking with tuberculosis infection: A cross-sectional study among 21008 rural residents in China. PLoS ONE. 12(4): 1-13. doi: 10.1371/journal.pone.0175183. 